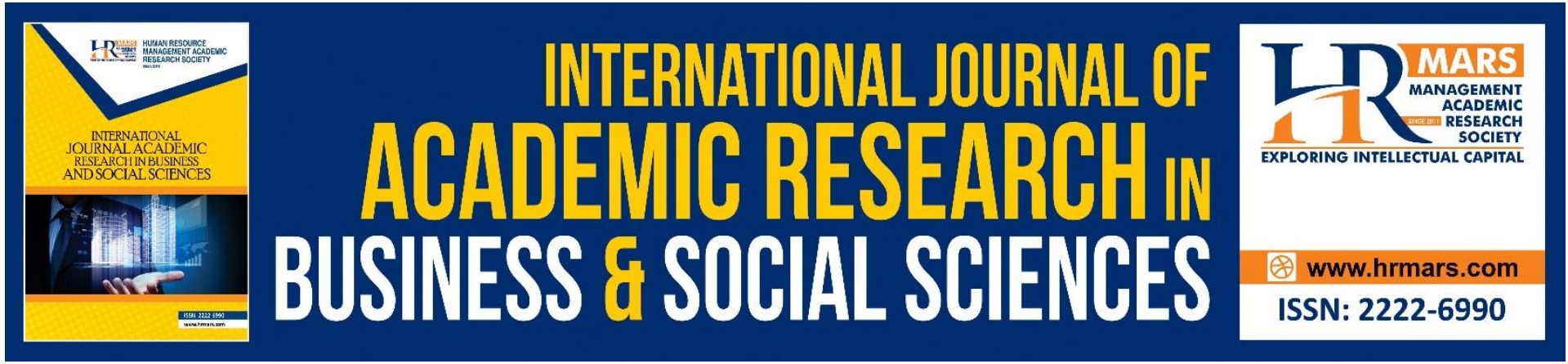

\title{
Move Structure of Malaysian Undergraduate Microbiological Science Thesis Abstracts
}

Muhamad Izzat Rahim, Mohd Zul Hadi Kamardin, Nurulnabilah Abdul Aziz

To Link this Article: http://dx.doi.org/10.6007/IJARBSS/v11-i8/10724

DOI:10.6007/IJARBSS/v11-i8/10724

Received: 05 June 2021, Revised: 02 July 2021, Accepted: 24 July 2021

Published Online: 06 August 2021

In-Text Citation: (Rahim et al., 2021)

To Cite this Article: Rahim, M. I., Kamardin, M. Z. H., \& Aziz, N. A. (2021). Move Structure of Malaysian Undergraduate Microbiological Science Thesis Abstracts. International Journal of Academic Research in Business and Social Sciences, 11(8), 227-238.

Copyright: (c) 2021 The Author(s)

Published by Human Resource Management Academic Research Society (www.hrmars.com)

This article is published under the Creative Commons Attribution (CC BY 4.0) license. Anyone may reproduce, distribute, translate and create derivative works of this article (for both commercial and non-commercial purposes), subject to full attribution to the original publication and authors. The full terms of this license may be seen at: http://creativecommons.org/licences/by/4.0/legalcode

Vol. 11, No. 8, 2021, Pg. 227 - 238

http://hrmars.com/index.php/pages/detail/IJARBSS

JOURNAL HOMEPAGE

Full Terms \& Conditions of access and use can be found at http://hrmars.com/index.php/pages/detail/publication-ethics 


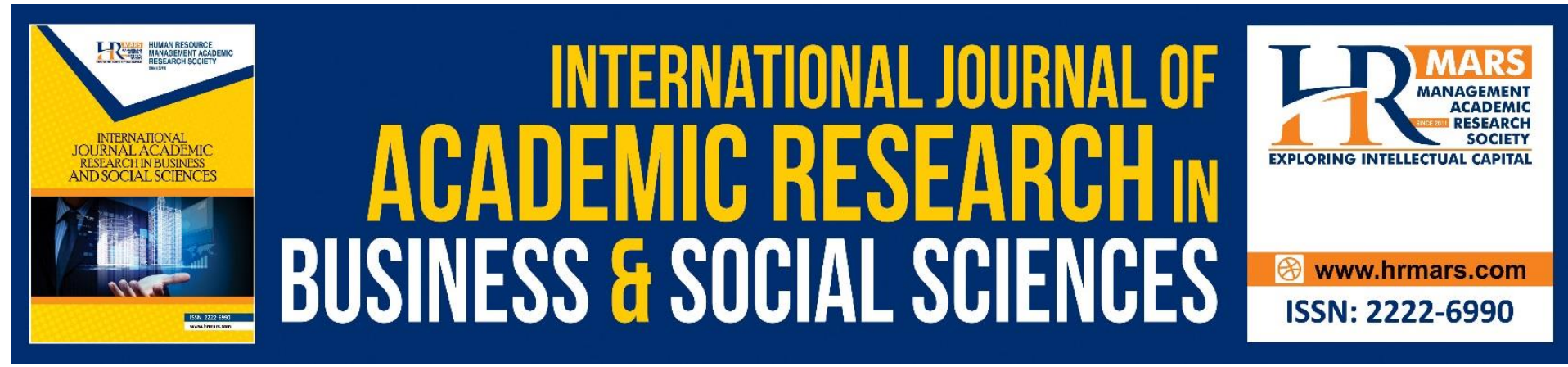

\title{
Move Structure of Malaysian Undergraduate Microbiological Science Thesis Abstracts
}

\author{
Muhamad Izzat Rahim¹, Mohd Zul Hadi Kamardin², \\ Nurulnabilah Abdul Aziz ${ }^{1}$ \\ ${ }^{1}$ Academy of Language Studies, UiTM Negeri Sembilan, Kuala Pilah 72000, Negeri Sembilan \\ Malaysia, ${ }^{2}$ Pusat Pemajuan Kompetensi Bahasa (CALC), Universiti Putra Malaysia, Malaysia
}

\begin{abstract}
Abstract is an important part of academic thesis. It summarises the thesis plus attracts readers to read the entire publication. However, little studies have been conducted to investigate the move structure of thesis abstract from the microbiological science field. To this end, the study aims to investigate the move structure of microbiological science thesis abstracts by Malaysian undergraduates. Thirteen thesis abstracts were analysed using move analysis to investigate the move structure, move status and move sequence. There were six moves found based on the analysis. All moves were deemed as obligatory except for one. Additionally, there were eleven move sequences found to be utilised in the abstracts. The findings could provide insight for both students and lecturers who are involved directly with thesis abstracts. Keywords: Undergraduate Thesis, Abstract, Microbiological Science, Move, Structure
\end{abstract}

\section{Introduction}

Abstract is an important part of academic publication. Indeed, as explained by Bhatia, (1993), abstract is a recognisable genre and widely accepted in many disciplines. Usually, abstract can be found accompanying academic publications such as books, report, thesis, research article and dissertation. A typical abstract commonly consists of an introduction, methodology, results, and conclusion. All these are written in one concise paragraph and placed as the first section of a publication.

The purpose of an abstract is to summarise the content of a publication. By summarizing the content, it can provide the gist of a publication to readers. Lorés (2004) equated abstract to a doorway for readers to the entire content of a publication. Additionally, a well-organised abstract can attract more readers as well as improve chances of a work to be published, indexed or cited (Al-Khasawneh, 2017).

Although most abstracts have similar purposes, there are variations on the way it is structured. Many scholars describe the structure of abstract using the term move (Swales, 1990; Bhatia, 1993; Swales \& Feak, 2012). Bhatia (1993) proposed a four-move structure for writing abstract. This structure consisted of four moves namely introducing the purpose, describing the method, summarising the result, and presenting the conclusion. In contrast, 
Swales \& Feak (2012) introduced a five-move generic structure of abstract. The structure consists of background, aim, method, results, and conclusion. Additionally, there is also variation in writing abstract when it comes to different discipline, writers' background of proficiency level. For example, Al-Khasawneh (2017) reported that research article abstracts written by native speakers of English consisted of different moves as compared to the ones written by non-native speakers. Similarly, Talebzadeh et al (2013) reported that Iranian writers tend to use different moves in writing the abstracts as compared to the native speakers of English.

Thus, realising the importance of abstract and its variations, this study aims to study the move structure of Malaysian microbiology undergraduate thesis abstracts. For the undergraduates, thesis is part of the graduate requirement set by the university. Thus, it is important for them to be able to write a good abstract to summarise their theses. Additionally, to date, little literature has been found on the move structure of abstracts written by students from microbiological field especially in Malaysian context. Hence, this study aims to fill in the gap by investigating the move structure, their status and later the sequence of move used in Malaysian microbiology undergraduate thesis abstracts. The followings are the research questions that guide this present study.

\section{Research Questions}

1. What are the moves of Malaysian microbiological science thesis abstracts?

2. What are the obligatory or optional moves of Malaysian microbiological science thesis abstracts?

3. What is the preferred move sequence of Malaysian microbiological science thesis abstracts?

\section{Literature Review}

Genre analysis focuses on the study of language usage in a particular setting (Swales, 1990). The aim of genre analysis is to break down the language to reveal its pattern and structure. The knowledge on structure and pattern of the language enables users to use the language more efficiently. Genre analysis is a versatile method where it can be used to study myriad of written language such as research articles (Brett, 1994), website (Zhang, 2017), editorial letters (Flowerdew \& Dudley-Evans, 2002) and job application letter (Paramasivam \& Rahim, 2016; Rahim \& Arifin, 2014). Additionally, genre analysis also can be used to study spoken language such as lectures (Lee, 2016; Malavska, 2016), podcast (Drew, 2017), video lectures (Rahim \& Shamsudin, 2020) and presentations (Hu \& Liu, 2018).

From the perspective of ESP genre tradition, the structure or pattern of language is described in term of its move. Swales (2004: 228-229) defined the word 'move' as "a discoursal or rhetorical unit that performs a coherent communicative function in a written or spoken discourse". Combination of moves creates the rhetorical structure of a discourse. Additionally, the combination of moves helps to realise the communicative purpose of a discourse.

Genre analysis has been at the centre of attention of many scholars because of the benefits that it brings. The findings of genre analysis may benefit parties involve with the discourse in a particular setting such as teachers, promoters, writers and interviewees (Bhatia, 
1993; Swales, 1990; Paramasivam \& Rahim, 2016). In ESP genre tradition, often the findings of genre analysis would benefit students by equipping them with salient language resources and information of a discourse. This would enable students to use the discourse effectively.

One discourse that has been at the centre of genre analysis studies is abstract. Abstract is an important part of an academic publication. Bhatia (1993: 78) defined abstract as "A description or factual summary of the much longer report and is meant to give the reader an exact and concise knowledge of the full article". Indeed, abstract introduces the gist of the entire publication to the reader. Thus, a well organised abstract can attract readers to read the publication (Al-Khasawneh, 2017). Additionally, it also can improve the chances of a publication to be indexed or cited.

Among the most well-known genre analysis of abstract was conducted by Bhatia (1993) where he investigated the abstract of research articles. Bhatia (1993) posed four questions that were significant in the building of research article abstract. The four questions were, What the author did?, How the author did it?, What the author found?, and What the author concluded?. In answering the four questions, he proposed a four-move structure namely introducing the purpose, describing the method, summarising the result, and presenting the conclusion. Each of the move was important as it answered the previously mentioned questions.

In contrast with Bhatia's (1993) findings, Swales and Feak (2012) proposed a five move generic structure. The five moves were background, aim, method, results, and conclusion. They called the moves as a structured abstract, and it is widely used by writers from myriad of discipline in writing research paper abstracts. Although Bhatia (1993) and Swales and Feak (2012) investigated research article abstracts, the latter found an extra move namely background. The extra move provides the overview of the study.

Other than the two aforementioned studies, there are other studies that investigate abstracts from various academic publication. Talebzadeh et al. (2013) conducted a comparative genre analysis on research article abstracts by Iranian students and native speakers of English. They found that although both groups of students used the Introduction, Method, Result, Discussion (IMRD) structure, there were slight differences in the usage of the move structure. Similarly Al-Khasawneh (2017) compared research article abstracts by native and non-native speakers of English. Overall, it was found that both native and non-native speakers used the same five moves (Introduction, Purpose, Method, Product and Conclusion). However, it was learned that the Introduction and Conclusion moves were used more frequently by native speakers as compared to the non-native speakers.

Hitherto, it can be said that abstracts, written by authors from different background have difference in terms of their structure. Hence, the mentioned studies proved that move structures of abstract have their own variation. The variation can be seen in the usage of moves. Some scholars like Bhatia (1993); Talebzadeh et al (2013) reported about four-move structure while Swales and Feak (2012); Al-Khasawneh (2017) reported on the usage of fivemove structure. 


\section{Methodology}

The data for this study was collected from a Diploma in Microbiology program from a Malaysian university. Thirteen abstracts were chosen for this study. All abstracts were written by final year diploma students from the same cohort. The abstracts were part of the students' thesis which was a graduation requirement. English was used as the main medium for the abstracts. Qualitative method was adopted for this study. To be exact, move analysis was used to analyse the collected abstracts. Swales and Feak (2012) five-move structure was used as the main reference for the analysis.

Before the abstracts were analysed, the data was first organised and labelled. As suggested by (Yin, 2011), data that is well-organised can lead to efficient analysis. For this purpose, firstly the abstracts were labelled A1 until A13 where A stands for abstract while the number is the label number for each abstract. This could help the researchers to analyse and report the findings in a more systematic way.

The genre analysis was firstly done in separation by the researchers. Later, the findings were compared. Any differences were thoroughly discussed to resolve any problems found. It was a recursive process until the analysis reached a point of saturation. Later, the results were tabulated, discussed, and reported.

For research question two, simple statistical calculation was conducted to determine the status of the moves. As suggested by scholars like Kanoksilapatham (2005) and Kosasih (2018), a move or step is considered as obligatory if it appears more than $60 \%$. In contrast, if a move or step appears less than $60 \%$ in the corpus, it would be considered as optional. The findings of the calculation were reported and discussed.

To answer the third research question, the findings of research question one was further analysed to determine the preferred sequence in the usage of move. Lastly, the sequences were reported and discussed.

\section{Results}

The study aims to answer three research questions. The first research question concerns about the move used in Malaysian microbiological science thesis abstracts. Move analysis was conducted thoroughly based on Swales and Feak's (2012) abstract's moves. In contrast with referred moves, the analysis found six moves applied in the abstracts. The six moves were Background, Aim, Method, Results, Suggestion and Conclusion.

One additional move was found namely Suggestion. The move was not suggested in previous studies such as Swales and Feak's (2012) abstract moves. Later, the number of occurrences of the moves was calculated and converted to percentage. This was to determine the obligatory or optional status of the move. Table 1 illustrates the moves based on the analysis.

Table 1. Malaysian Undergraduate Microbiological Science Thesis Abstracts Moves

\begin{tabular}{|c|l|l|}
\hline Moves & Percentage/ Total & Obligatory/Optional \\
\hline 1. Background & $100 \%(13)$ & Obligatory \\
\hline 2. Aim & $61.5 \%(8)$ & Obligatory \\
\hline 3. Method & $92.3 \%(12)$ & Obligatory \\
\hline 4. Results & $92.3 \%(12)$ & Obligatory \\
\hline 5. Suggestion & $7.6(1)$ & Optional \\
\hline 6. Conclusion & $53.8 \%(7)$ & Obligatory \\
\hline
\end{tabular}


Background was the first move found based on the analysis. All thirteen abstracts used this move. This made the move as obligatory. The purpose of this move was to contextualise the research in order to help readers understand the past, present or future situation of the research. Additionally, the move also acted as attention grabber that can help to market the publication to those who are interested in the particular field (Al-Khasawneh, 2017). Overall, it can be said that this move played the role of introduction that set the scene for the readers to understand more about the research. Table 2 shows few examples of this move from the analysed abstracts.

Table 2. Examples of Background

\begin{tabular}{|l|l|}
\hline Abstract & Examples \\
\hline A2 & $\begin{array}{l}\text { Toilet cleaners are usual acidic and take two forms: liquids and powder. } \\
\text { Many of these products are considered corrosive. Cleaning compositions } \\
\text { that effectively disinfect and clean hard surfaces such as those in lavatories } \\
\text { and bathrooms, particularly toilet bowls, are well known. }\end{array}$ \\
\hline A3 & $\begin{array}{l}\text { Water is an important source in our daily life. Contamination of water supply } \\
\text { is crucial if there is no action taken to avoid such illegal waste discharge to } \\
\text { water supply. }\end{array}$ \\
\hline A6 & $\begin{array}{l}\text { Tenderising agent is the material that is used in a process to break down } \\
\text { collagens in meat to make it more palatable for consumption. It is commonly } \\
\text { in current with the using of tenderising agent that consists of various } \\
\text { chemical reagents in tenderising the meat. Usually, they can appropriate } \\
\text { with our body but can be harmful if they do not take any action to avoid } \\
\text { using them frequently. }\end{array}$ \\
\hline
\end{tabular}

The examples show that most writers preferred to introduce the keywords of the research at the beginning of this move. Words like Tenderising agent, water and toilet cleaners were all keywords to the studies in the examples. Presumably, this helps readers to quickly grasp the key concept of the studies. Right after the keywords, the writers gave more information of the studies by explaining the definition or current situation of the keywords. Thus, it can be said that the purpose of Move 1: Background was to provide basic information before going into the details of the studies.

The second move was Aim. In this move, the writers explained to the readers of the purposes or objectives of the research (Swales and Feak, 2012). Eight abstracts employed this move where it regularly occurred after the first move Background. This move was considered as an obligatory move since it occured more than $60 \%$. Commonly, writers used verbs such as determine, find, study, aim and investigate. Some examples of the second move can be seen in Table 3. 
Table 3. Examples of Aim

\begin{tabular}{|l|l|}
\hline Abstract & Examples \\
\hline A1 & $\begin{array}{l}\text { The objectives for this research are to determine the growth of plant using } \\
\text { hydroponic system and to measure the concentration of heavy metals that } \\
\text { can be absorbed by the plant }\end{array}$ \\
\hline A5 & $\begin{array}{l}\text { The study of determination of population bacteria in soil was conducted to } \\
\text { isolate and enumerate the bacteria population in soil which is finely ground } \\
\text { soil, ground fuel, and peat soil. }\end{array}$ \\
\hline A6 & $\begin{array}{l}\text { In this thesis, the experiment aimed in finding a solution to cut often uses of } \\
\text { chemical tenderising agent. The experiment presented the comparing of } \\
\text { best meat tenderiser between different types of leaves. For this experiment, } \\
\text { papaya leaves and pineapple leaves were used to determine the best } \\
\text { tenderiser and looking up more in determining whether solid or liquid state } \\
\text { of leaves is the best meat tenderiser. }\end{array}$ \\
\hline
\end{tabular}

Although scholars like Swales and Feak (2012) posited that stating the aims of study is important, it was found that five abstracts did not utilise this move. The five abstracts were abstract A4, A8, A9, A11 and A12. The explanation of aims for those five abstracts were missing. Instead, the writers utilised other moves such as Move 1: Background and Move 3: Method to construct the abstracts. Consequently, this might hinder a clear understanding of the abstracts since there were no clear indications of what the studies would like to achieve.

It was found that the next move was Method. In this third move, writers illustrated the methodologies of the studies. The move included explanation on materials used, subjects of studies and procedure of studies (Swales and Feak, 2012). All but one abstract (A7) employed this move. The high number of abstracts using this move shows that this move was an obligatory move. This finding lends support to Melander et al. (1997) claim when they stated that abstracts in science field tend to focus more on what was done (method) and what was found (result). Similar to Move 1: Background, this move was considered as an obligatory move. It would be difficult to understand a study if this move was omitted (Puo, 2008). Examples of Move 3: Method are as illustrated in Table 4. 
Table 4. Examples of Method

\begin{tabular}{|l|l|}
\hline Abstract & Examples \\
\hline \multirow{3}{*}{ A10 } & $\begin{array}{l}\text { Total phenolic content was determined using Folin-Ciocalteu reagent } \\
\text { method based on the standard calibration curve of Gallic acid measured at } \\
750 \mathrm{~nm} \text { using UV-Visible Spectrometer (Perkin Elmery). }\end{array}$ \\
\hline A11 & $\begin{array}{l}\text { The method used are to derive the cadmium through laboratory work and } \\
\text { prepare them in different concentrations (1-1000ppm). This is prior to } \\
\text { determine which concentration works best for bioremediation of cadmium } \\
\text { using Pseudomonas sp. Spectrophotometric analysis by comparing } \\
\text { concentration of before and after bioremediation was used for this purpose. } \\
\text { Scanning the cd solution in the spectrophotometer was done and maximum } \\
\text { wavelength of 195nm was obtained. }\end{array}$ \\
\hline A13 & $\begin{array}{l}\text { We estimate the ripe of fruit by observe the colour changes either the fruits } \\
\text { is darkened or not after testing it with an iodine solution and Benedict's } \\
\text { reagent. We used spectrophotometer with a wavelength of 580nm to } \\
\text { measure the absorbance of the sample. This instrument will provide } \\
\text { measuring the amount of material in the solution so that we will know the } \\
\text { amount of starch present for every tested fruit. }\end{array}$ \\
\hline
\end{tabular}

The fourth move was Results. In this move, writers explained what was discovered based on the aims and methods mentioned previously. It briefly summarised and reported the major findings of the study. It was found that twelve abstracts utilised this move. However, the move was missing in abstract A3. This obligatory move was considered important since it can be used to sell or promote the study to the same research community (Van Bonn \& Swales, 2007). It is argued that without this move, the abstract could lose its persuasiveness thus hinder readers to read the study entirely. This move is best illustrated by abstracts $A 2, A 5, A 7$ and $A 9$ as presented in Table 5 .

Table 5. Examples of Results

\begin{tabular}{|l|l|}
\hline Abstract & Examples \\
\hline \multirow{4}{*}{ A2 } & $\begin{array}{l}\text { Based on the observation, it was found that bacteria F, coli avoiding the cleaning agent A is } \\
\text { Even though the results showed that all of the cleaning agent used were able to effectively } \\
\text { kill E. coli, cleaning agent B was the most effective cleaning agent use to inhibit and kill the } \\
\text { bacteria. }\end{array}$ \\
\hline A9 & $\begin{array}{l}\text { The result in this investigation, the average colony forming unit CFU/mL for viable count for } \\
\text { soil A, soil B and soil Care } 5.6 \times 10^{3} \mathrm{CFU} / \mathrm{mL}, 3.7 \times 10^{3} \mathrm{CFU} / \mathrm{mL} \text { and } 1.2 \times 10^{3} \mathrm{CFU} / \mathrm{mL} \text { respectively. } \\
\text { Then the Gram staining for soil A, soil B and soil Care gram positive, gram negative and gram } \\
\text { environment factors that soil have decompose of organic material. }\end{array}$ \\
\hline \multirow{3}{*}{ A12 } & $\begin{array}{l}\text { The results show that milk A have } 0.852 \mathrm{~g} \text { of lactose and } 0.3356 \mathrm{~g} \text { of casein, milk B have } \\
\text { of casein. Therefore, milk A has the highest amount of lactose compare to other milk brand } \\
\text { and milk B has the highest amount of casein compare to the other brand. }\end{array}$ \\
\hline $\begin{array}{l}\text { The results show that the absorbance of vitamin A in carrot is } 0.82 \mathrm{~A}, 0.49 \mathrm{~A} \text { in spinach and } \\
0.20 \mathrm{~A} \text { in eggplant. We obtained the most clearly blue colour seen is carrot followed by } \\
\text { spinach which is blur and finally the eggplant which is no blue colour can be seen. This is } \\
\text { because TFA is reacting with vitamin A and a blue solution will be formed. So we will observe } \\
\text { the blue colour formed which is concentrated or dilute. }\end{array}$
\end{tabular}

The examples show that the move did not only focus on findings. In fact, it also contained some argument or discussion of the results (Al-Khasawneh, 2017). Thus, this move is an important one as it reports the findings and discusses the results in terms of its 
implication and reasoning. Therefore, by missing this move might hamper the understanding of the readers.

One abstract was found to utilise an extra move namely Suggestion. Abstract A4 employed Move 5: Suggestion right after Move 4: Results. In this move, the writer was making suggestion for future studies. This move was not reported in any previous abstract moves such as the ones from Swales and Feak (2012). Thus, it can be said that this move is unique to abstract belonging to undergraduate microbiology thesis. However, this was an optional move since only one abstract employed this move. Table 6 shows the move from abstract A4.

Table 6. Example of Suggestion

\begin{tabular}{|l|l|}
\hline Abstract & Examples \\
\hline A4 & $\begin{array}{l}\text { We suggested using the milk that has been kept in the room for the } \\
\text { production of milk because the } \mathrm{pH} \text { is not too acidic acid added to the milk, } \\
\text { the } \mathrm{pH} \text { becomes more acidic which is 4.9. However, after cooling process and } \\
\text { the milk becomes curdle, the } \mathrm{pH} \text { is 9.65. Therefore, the glue will become } \\
\text { alkaline and safe to use. }\end{array}$ \\
\hline
\end{tabular}

The last move found from the analysis was Conclusion. Basically, Move 6: Conclusion was the last move found in the abstract. Seven abstracts were found to utilise this move. In this sixth move, writers need to summarise and close the abstract. Swales and Feak (2012) also suggested that in this move, writers can make discussion or report on the significance of the study. Most writers used conjunctions to signal the start of this move. Some conjunctions that were commonly used by the writers were as conclusion, therefore and as the conclusion. Examples of Move 6: Conclusion can be seen in Table 7.

Table 7. Examples of Conclusion

\begin{tabular}{|l|l|}
\hline Abstract & Examples \\
\hline A4 & $\begin{array}{l}\text { As conclusion, the glue that we produce from this experiment is safe because } \\
\text { we do not use artificial material or chemical. }\end{array}$ \\
\hline A8 & $\begin{array}{l}\text { As conclusion, milk A is not good for people who have lactose intolerant and } \\
\text { milk B is not preferable for a person who have casein intolerant. }\end{array}$ \\
\hline A9 & $\begin{array}{l}\text { Based on our project, we can conclude that soybean have a highly } \\
\text { concentration which mean it has high antioxidant. Its contain isoflavone that } \\
\text { have antioxidant activity among to others. }\end{array}$ \\
\hline
\end{tabular}

In terms of Move sequence, there were eleven sequences of moves found from the abstracts. The shortest sequence consisted of three moves. There were three sequences with three moves namely Background-Aim-Method (A3), Background-Aim-Results (A7) and Background-Method-Results (A12). On the other hand, the longest sequence consisted of six moves namely Background-Aim-Background-Method-Results-Conclusion (A5) and Background-Method-Aim-Results-Aim-Results (A13). The most used sequence was the fivemove sequence which was Background-Aim-Method-Results-Conclusion (A1, A6, A10). The other move sequences were represented by only one abstracts. Table 8 shows the Move sequence used in each abstract while Table 9 shows the frequency of every Move sequence found in this study. 
Table 8. Move Sequence

\begin{tabular}{|l|l|l|l|}
\hline Abstract & Move Sequence & Abstract & Move Sequence \\
\hline A1 & B-A-M-R-C & A8 & M-R-C-R \\
\hline A2 & B-A-B-M-R & A9 & B-M-R-C \\
\hline A3 & B-A-M & A10 & B-A-M-R-C \\
\hline A4 & B-M-R-S-C & A11 & B-R-B-M-R \\
\hline A5 & B-A-B-M-R-C & A12 & B-M-R \\
\hline A6 & B-A-M-R-C & A13 & B-M-A-R-A-R \\
\hline A7 & B-A-R & $\begin{array}{l}\text { B-Background A-Aim M-method R-Result } \\
\text { S-Suggestion C-Conclusion }\end{array}$ \\
\hline
\end{tabular}

Table 9. Frequency of Move Sequence

\begin{tabular}{|l|l|}
\hline Move Sequence & Frequency \\
\hline B-A-M-R-C & 3 \\
\hline B-A-B-M-R & 1 \\
\hline B-A-M & 1 \\
\hline B-M-R-S-C & 1 \\
\hline B-A-B-M-R-C & 1 \\
\hline B-A-R & 1 \\
\hline M-R-C-R & 1 \\
\hline B-M-R-C & 1 \\
\hline B-R-B-M-R & 1 \\
\hline B-M-R & 1 \\
\hline B-M-A-R-A-R & 1 \\
\hline
\end{tabular}

\section{Discussion}

In terms of pedagogy, the results of this study may shed some light to the move structure of abstracts. Thus, it can provide insights on what to focus in teaching the students on how to write an effective abstract. As a result, students can become discourse competent. As explained by Kaplan and Knudson (1993:167) discourse competence means "the ability to produce and understand those features of extended speech or writing which facilitate connectedness and cohesion". In other words, the findings of this study may assist students to become competent writers.

It was found that some writers omitted obligatory moves such as Move 2: Aim (A4, A8, A9, A11, A12) and Move 3: Method (A7). Thus, it is suggested that students need to be taught the importance of these obligatory moves. Lecturers can explain to students the function of these moves and how they can help in writing good abstracts. Without these moves, abstracts are incomplete and could not convey the gist of the thesis. Additionally, the omission of these moves might create confusion for readers while reading it. Eventually, readers might lose interest to read the abstract and the thesis entirely. Moreover, students also can be taught about the most suitable sequence of moves in writing abstracts. A well organised abstract can help writers to convey the important information of the thesis such as aim, method and results. On the other hand, an abstract that does not have a systematic structure might create confusion for readers. 


\section{Conclusion}

Motivated by the importance of abstract, this study aims to investigate the move structure of Malaysian microbiological undergraduate thesis abstracts. Thirteen abstracts from a cohort of microbiology undergraduates were analysed using Swales and Feak's (2012) abstract moves. The analysis was guided by three research questions that focused on the moves utilised in the abstract, their status, and the sequence of moves.

The analyses show that Malaysian microbiological undergraduate thesis abstracts have six moves namely Background, Aim, Method, Results, Suggestion and Conclusion. Five moves are found as obligatory moves while one move (suggestion) is an optional move. The analysis also reveals that the Move 5: Suggestion is an extra move which is not found in previous studies. Concerning the sequence of the moves, eleven sequences were found. The most utilised sequence was the Background-Aim-Method-Results-Conclusion (A1, A6, A10).

Additionally, it is suggested that the findings of this study may be pedagogically beneficial. Lecturers can utilise the findings to teach students on writing abstract systematically. However, cautious must be practiced in utilising the findings of this study. This is because, this study only investigated a small number of abstracts that belong to a cohort of undergraduate students in the field of microbiology. Thus, the findings could not be generalised to all undergraduate students. As shown in previous studies, abstracts can be written in myriad of ways. Hence, it is suggested that further study can be conducted to understand more about this genre. Future studies can manipulate different variables such as English language ability, different field of study or level of study. It is also suggested to utilise a larger corpus of abstracts. Utilising these variables may yield different results in future studies. Consequently, it can shed more lights toward this important genre.

\section{Corresponding Author}

Muhamad Izzat Rahim

Academy of Language Studies, UiTM Negeri Sembilan, Kuala Pilah 72000, Negeri Sembilan, Malaysia

Email: izzatrahim@uitm.edu.my

\section{References}

Al-Khasawneh, F. M. (2017). A Genre Analysis of Research Article Abstracts Written by Native and Non-Native Speakers of English. Journal of Applied Linguistics and Language Research, 4(January), 1-13.

Bhatia, V. K. (1993). Analyzing Genre: Language Use in Professional Settings. Longman.

Brett, P. (1994). A genre analysis of the results section of sociology articles. English for Specific Purposes. https://doi.org/10.1016/0889-4906(94)90024-8

Drew, C. (2017). Educational podcasts: A genre analysis. E-Learning and Digital Media, 14(4), 201-211. https://doi.org/10.1177/2042753017736177

Flowerdew, J., \& Dudley-Evans, T. (2002). Genre Analysis of Editorial Letters to International Journal Contributors. In Applied Linguistics. https://doi.org/10.1093/applin/23.4.463

Hu, G., \& Liu, Y. (2018). Three minute thesis presentations as an academic genre: A crossdisciplinary study of genre moves. Journal of English for Academic Purposes, 35, 16-30. https://doi.org/10.1016/j.jeap.2018.06.004

Hyland, K. (2002). Genre: Language, Context and Literacy. Annual Review of Applied Linguistics, 22(1), 113-135. https://doi.org/10.1017/s0267190502000065

Kanoksilapatham, B. (2005). Rhetorical structure of biochemistry research articles. English for 
Specific Purposes, 24(3), 269-292. https://doi.org/10.1016/j.esp.2004.08.003

Kaplan, M. A., \& Knudson, E. (1993). Where is the text? Discourse competence and the foreign language textbook. Mid-Atlantic Journal of Foreign Language Pedagogy, 1, 167-176.

Kosasih, F. R. (2018). A Genre Analysis of Thesis Abtracts at a State University in Banten. Lingua Cultura, 12(1), 9. https://doi.org/10.21512/lc.v12i1.1963

Lee, J. J. (2016). "There's intentionality behind it ...": A genre analysis of EAP classroom lessons. Journal of English for Academic Purposes, 23, 99-112. https://doi.org/10.1016/j.jeap.2015.12.007

Lorés, R. (2004). On RA abstracts: From rhetorical structure to thematic organisation. English for Specific Purposes, 23(3), 280-302. https://doi.org/10.1016/j.esp.2003.06.001

Malavska, V. (2016). Genre of an Academic Lecture. International Journal on Language, Literature and Culture in Education, 3(2), 56-84. https://doi.org/10.1515/Ilce-2016-0010

Melander, B., Swales, J. M., \& Fredrickson, K. M. (1997). Journal abstracts from three academic fields in the United States and Sweden: national or disciplinary proclivities? Culture and Styles of Academic Discourse, 251-272. https://doi.org/10.1515/9783110821048.251

Paramasivam, S., \& Rahim, M. I. Bin. (2016). Genre analysis of job application letters in Malaysia. Asian ESP Journal, 12(2), 144-170.

Puo, P. D. (2008). Research article abstracts in applied linguistics and educational technology a study of linguistic realizations of rhetorical structure and authorial stance. Discourse Studies, 10(2), 231-250. https://doi.org/https://doi.org/10.1177/1461445607087010

Rahim, M. I., \& Arifin, M. Z. (2014). Analysis of schematic structure of job application letters of a Malaysian company. Esteem Academic Journal, 10(2), 114-123.

Swales, J. M. (1990). Genre Analysis. English in Academic and Research Settings. Cambridge University Press.

Swales, J. M. (2004). Research Genres: Explorations and Applications. Cambridge University Press.

Swales, J. M., \& Feak, C. B. (2012). Academic Writing for Graduate Students: Essential Tasks and Skills (3rd ed.). The University of Michigan Press.

Talebzadeh, H., Ghafar Samar, R., Kiany, G. R., \& Akbari, R. (2013). Steps to a successful abstract: A comparative genre analysis. The International Journal of Humanities, 20(3), $1-25$.

Van Bonn, S., \& Swales, J. M. (2007). English and French journal abstracts in the language sciences: Three exploratory studies. Journal of English for Academic Purposes, 6(2), 93108. https://doi.org/10.1016/j.jeap.2007.04.001

Yin, R. K. (2011). Qualitative research from start to finish. Guilford Press.

Zhang, T. (2017). The Marketization of Higher Education Discourse: A Genre Analysis of University Website Homepages in China. Higher Education Studies, 7(3), 64-79. https://doi.org/10.5539/hes.v7n3p64 